\title{
Faktor Penyebab Kejadian Stunting di Kampung Tawang Negri Wilayah Kerja Payung Rejo Lampung Tengah Tahun 2019
}

\section{Causes of Factor Stunting Events at Tawang Negri in Payung Rejo Public Health Center Central Lampung 2019}

\author{
Ricky Dwi Satria1, Samino Martono ${ }^{2}$, dan Christin AF $^{2}$ \\ ${ }^{1}$ Fakultas Kedokteran Universitas Malahayati,, Bandar Lampung,Indonesia \\ ${ }^{2}$ Fakultas Kesehatan Masyarakat Universitas Malahayati, Bandar Lampung, \\ Indonesia \\ *korespondensi Penulis: dr.rickydsatria@gmail.com
}

Penyerahan: 29-02-2020, Perbaikan: 23-03-2020, Diterima: 12-04-2020

\begin{abstract}
The incidence of stunting is one of the nutritional problems of children. Central Lampung has a high stunting rate. One of them in Tawang Negri Village, which has a stunting rate of $44,16 \%$. This rate is relatively high because nutritional problems are good if short children are less than 20\%. Data for exclusive breastfeeding for the sixth month in Payung Rejo Community Health Center in 2018 was 42,70\%. The data shows a number below the Minimum Service Standards. The purpose of this study was to determine the cause of stunting base on specific interventions. This research used a qualitative in September - December 2019. Informants were divided into primary informants, a mother with stunting children, the key informants are nutrition coordinators at the Public Health Center and Health Office, and Caders as Triangulation. Retrieval of data using depth interview. The Analysis of data uses data collection, data reduction, presentation, and conclusion. Most informants did not understand about stunting either from the definition, causes, prevention, and impact. All informants claimed that they had given exclusive breastfeeding for the sixth month. Complimentary food was routinely given 2-3 times a day, but the type of food provided does not variations. Information Knowledge that is only limited in "knowing levels" impacts ignorance of understanding an applying the knowledge possessed to prevent stunting. So it can increase the percentage of stunting. Therefore it is essential to be made of group discussion when approaching family to provide knowledge to the community for prevention efforts independently.
\end{abstract}

Keywords: Stunting, Exclusive Breasfeeding, Complementary Foods, Family Approach.

\begin{abstract}
ABSTRAK
Kejadian stunting atau balita pedek merupakan salah satu masalah gizi yang di alami oleh balita. Kabupaten Lampung Tengah memiliki angka stunting cukup tinggi pada pada Provinsi Lampung. Salah satunya yaitu Kampung Tawang Negri yang memiliki angka stunitng $44,16 \%$. Angka ini terbilang cukup tinggi karena kategori masalah gizi baik jika balita pendek kurang dari 20\%. Data pemberian ASI ekskusif selama 6 bulan di Wilayah Kerja Puskesmas Payung Rejo pada tahun 2018 yaitu 42,70\%. Data tersebut menunjukkan angka dibawah Standar Pelayanan Minimum. Tujuan dari penelitian ini untuk diketahui penyebab kejadian stunting berdasarkan intervensi spesifik. Penelitian ini menggunakan pendekatan kualitatif pada bulan September - Desember tahun 2019. Informan dibagi menjadi informan utama yaitu ibu dengan anak stunting yang berjumlah empat orang, informan kunci yaitu koordinator gizi Puskesmas dan Dinas Kesehatan, dan Kader sebagai triangulasi. Pengambilan data menggunakan wawancara yang
\end{abstract}


mendalam (Deep Interview). Analisis data menggunakan pengumpulan data, reduksi data, penyajian data dan kesimpulan dari analisis data. Sebagian besar informan belum memahami Stunting baik dari pengertian, penyebab, pencegahan dan dampak. Semua informan mengaku sudah memberikan ASI Eksklusif selama enam bulan. MPASI rutin diberikan 2-3 kali sehari namun untuk jenis makanan yang diberikan tidak bervariasi.

Pengetahuan informan yang sebatas "tahu" berdampak pada ketidak mampuan dalam memahami maupun mengaplikasikan ilmu pengetahuan yang dimiliki dalam melakukan upaya pencegahan stunting, sehingga dapat meningkatkan angka kejadian stunting. Maka dari itu perlu dilakukan grup diskusi yang rutin saat melakukan pendekatan keluarga, untuk memberikan pengetahuan kepada masyarakat secara menyeluruh sehingga mampu melakukan upaya pencegahan secara mandiri.

Kata Kunci : Stunting, ASI Eksklusif, MPASI, Pendekatan Keluarga

\section{PENDAHULUAN}

Stunting merupakan salah satu masalah gizi di dunia yang dialami oleh balita. Tahun 2017 jumlah anak stunting di dunia adalah 150,8 juta balita (22,2\%). Namun sudah terjadi penurunana jika dibandingkan pada tahun 2000 dengan angka kejadian stunting di dunia berjumlah 32,6\%. Pada tahun 2017, Asia merupakan benua dengan angka kejadian stunitng cukup tinggi yaitu dengan perkiraan hampir dari setengah balita di dunia atau 55\%, diikuti oleh benua afrika dengan perkiraan hampir sepertiganya yaitu 39\%. Dari 83,6 juta balita stunting di Asia, angka kejadian stunting terbanyak ada di Asia Selatan berjumlah 58,7\% dan angka kejadian stunting paling sedikit di Asia Tengah berjumlah $0,9 \%$. Menurut data WHO, Indonesia merupakan negara urutan ketiga dengan angka kejadian stunting tertinggi di wilayah Asia Tenggara. Rata-rata angka kejadian stunting di Indonesia dari tahun 2005 hingga 2017 adalah 36,4\% (Kemenkes, 2018b).

Tahun 2018, Lampung Barat $32.93 \%$, Tanggamus 28.87\%, Lampung Selatan 29.08\%, Lampung Timur 24.71\%, Lampung Tengah $25.32 \%$, Lampng Utara 26.64\%, Way Kambas $35.07 \%$, Tulang Bawang 32.49\%, Pesawaran
$27.49 \%$, Pringsewu 20.19\%, Mesuji $23.16 \%$, Tulang Bawang Barat 27.2\%, Bandar Lampung 25.14\%, Metro 14.75\% (Kemenkes, 2018a).

Walaupun terjadi penurunan angka kejadian stunting di berbagai Kabupaten Lampung, tapi ada beberapa lokus seperti di kecamatan Lampung Tengah masih memiliki persentase jumlah balita stunting cukup tinggi, seperti pada Puskesmas Payung Rejo Kecamatan Pubian memiliki tiga wilayah kerja yaitu Kampung Payung Dadi dengan jumlah balita 283 jiwa dan terdapat jumlah balita stunting 63 jiwa (22.26\%), Kampung Padang Rejo memiliki jumlah balita 108 dengan jumlah balita yang terkena stunting 22 jiwa (20.37\%) dan yang tertinggi terletak pada Kampung Tawang Negri dengan jumlah balita 77 jiwa dan dari 77 balita terdapat 34 jiwa yang mengalami stunting atau sekitar 44,16\% (E-PPGBM, 2019). Berdasarkan pengertian kategori masalah gizi masyarakat angka kejadian pendek dalam suatu wilayah dikatakan kategori baik bila balita pendek kurang dari 20\% dan kurus kurang dari 5\% sedangkan jika suatu wilayah dikatakan mengalami masalah gizi akut bila angka kejadian balita pendek lebih dari $20 \%$ dan angka kejadian balita 
kurus lebih dari 5\% (Kemenkes, 2018b).

Untuk mencegah ataupun mengurangi dampak kejadian stunting pemerintah menetapkan upaya pencegahan sesuai dengan Peraturan Mentri Kesehatan No. 36 tahun 2016 tentang Pedoman Penyelenggaraan Program Indonesia Sehat dengan Pendekatan Keluarga, yaitu suatu usaha yang dilakukan untuk menurunkan angka kejadian stunting yang diantaranya seperti, Intervensi pada $1.000 \mathrm{HPK}$, menyelenggarakan makanan Tinggi Kalori, Protein dan Mikronutrien, menyelenggarakan konseling Inisiasi Menyusu Dini (IMD) dan ASI Ekslusif dan lain sebagainya (Kemenkes, 2018b). Dari penelitian Ramadhan (2018), penyebab utama terjadinya stunting adalah pemberian ASI yang tidak adekuat (Ramadhan, Ramadhan and Fitria, 2018). Data ASI Ekslusif selama 6 bulan pada tahun 2018 di Wilayah Kerja Puskesmas Payung Rejo Lampung Tengah hanya sebesar $42,70 \%$ yaitu dibawah Standar Pelayanan Minimum sebesar $50 \%$, sedangkan anjuran dari Kementrian Kesehatan anak baru lahir diberikan ASI ekslusif sampai usia enam bulan dipersentasikan harus mencapai $100 \%$. Tujuan penelitian ini untuk diketahui penyebab kejadian stunting di Kampung Tawang Negri. Berdasarkan intervensi spesifik yang terdiri dari tingkat pengetahuan, cara pemberian ASI, cara pemberian MPASI, dan program yang sudah di laksanakan oleh pelayanan kesehatan.

\section{METODE PENELITIAN}

Penelitian dilakukan dengan menggunakan pendekatan kualitatif dengan pendekatan studi kasus dimana memungkinkan peneliti mengumpukan informasi yang rinci dan kaya, mencakup dimensidimensi sebuah kasus tertentu atau beberapa kasus kecil dalam rentang yang luas dan studi kasus merupakan strategi yang cocok bila pokok pertanyaan suatu penelitian berkenaan dengan "kenapa" dan "bagaimana", bila penelitian hanya memiliki sedikit peluang untuk mengendalikan peristiwa-peristiwa yang akan diselidiki dan bilamana fokus penelitiannya terletak pada fenomena masa kini dalam konteks kehidupan nyata (Evi Martha, 2016). Penelitian ini dilakukan di Kampung Tawang Negri wilayah kerja Puskesmas Payung Rejo Lampung Tengah. Penelitian ini telah dilaksanakan pada bulan September - Desember 2019.

Kriteria inklusi informan yaitu ibu hamil anak pertama atau kedua yang stunting (usia 12-24 bulan), bersedia menjadi responden atau informan dan dapat berkomunikasi dengan baik. Kriteria ekslusi, yaitu ibu dengan ASI yang tidak keluar, ibu dengan kelainan anatomi puting susu (Inverted Nipple), dan ibu yang tidak bersedia menjadi informan. Sampling atau proses pemilihan kelompok individu untuk dimasukkan ke dalam penelitian yaitu menggunakan teknik non-probabillity tujuannya untuk memilih kasus yang sesuai dan kaya informasi, teknik yang digunakan adalah purposive sampling yaitu jenis sampling yang banyak digunakan dalam penelitian kualitatif dimana jumlah sampel bisa ditentukan sebelum penelitian atau pada saat peelitian berlangsung, bergantung pda sumber data yang ada, tersedianya waktu penelitian, serta bergantung pada tujuan penelitian (Evi Martha, 2016).

Analisis data adalah kegiatan yang terkait dengan upaya memahami, 
menjelaskan, menafsirkan dan mencari hubungan diantara data data yang diperoleh. Analisis data pada penelitian ini menggunakan model interaktif. Analisis model interaktif merupakan teknik analisis dimana tiga komponen dalam analisis dilakukan dengan cara aktivitas yang berbentuk interaksi antar komponen dan proses pengumpulan data sebagai proses siklus. Menurut Miles dan Hubermen dalam Sugiyono (2018) menjelaskan tahap dalam analisis model interaktif yaitu reduksi data, penyajian data dan verifikasi atau kesimpulan (Sugiyono, 2018). Penelitian ini dilakukan dengan maksud menilai penyebab kejadian stunting di Kampung Tawang Negri wilayah kerja Payung Rejo Lampung Tengah Penelitian ini dilakukan setelah terlebih dahulu melakukan kelaikan etik di Komisi Etik Penelitian Kesehatan Universitas Malahayati dengan nomer: 607/EC/KEPUNMAL/XI/2019.

\section{HASIL}

Tabel 1. Data ASI Eksklusif, MPASI dan Anemia pada ibu Hamil

\begin{tabular}{lcccc}
\hline \multicolumn{5}{c}{ Kampung Tawang Negri } \\
\hline \multicolumn{1}{c}{ Data } & Ya & Tidak & Jumlah & \% \\
\hline ASI Eksklusif & 9 & 4 & 13 & 69,2 \\
MPASI pabrikan & 51 & 18 & 69 & 73,9 \\
Anemia Ibu Hamil & 2 & 12 & 14 & 14,2 \\
\hline
\end{tabular}

Dari tabel 1 didapatkan bahwa bayi yang ASI eksklusif berjumlah 9 orang dari total 13 bayi $(69,2 \%)$. Jumlah anak balita yang dapat MPASI pabrikan berjumlah 51 dari 69 balita (73,9\%). Jumlah Anemia pada ibu hamil yaitu 2 orang dari 12 orang $(14,2 \%)$.

\section{Pengetahuan tentang Stunting}

Dari hasil wawancara mendalam kepada informan tentang pengertian stunting diperoleh bahwa informan mengatakan pengertian stunting adalah kurang gizi. Selanjutnya dari wawancara terkait penyebab stunting diperoleh bahwa penyebab kejadian diakibatkan oleh kurang gizi. Kemudian wawancara tentang pencegahan stunting didapatkan bahwa informan menyatakan pencegahan dari stunting yaitu diberikan makan-makanan bergizi. Wawancara mengenai dampak stunting didapatkan bahwa informan menyatakan adanya penurunan kognitif dikarenakan kekurangan gizi.

\section{Inisiasi Menyusu Dini, ASI Eksklusif, MP-ASI}

Dari wawancara mendalam tentang pelaksanaan IMD didapatkan bahwa seluruh informan telah melakukan inisiasi menyusu dini. Sesuai dengan pernyataan informan kunci, bahwasanya puskesman dan bidanbidan desa telah melakukan IMD. Selanjutnya Informan triangulasi yaitu kader juga menyatakan hal yang sama bahwasanya IMD sudah dilakukan.

Dari wawancara mendalam didapatkan bahwa seluruh informan sudah memahami pengertian dari ASI adalah air susu ibu. Selanjutnya pelaksanaan pemberian ASI eksklusif dari wawancara ditemukan bahwa seluruh informan telah melakukan ASI eksklusif selama 6 bulan dan frekuensi pemberian ASI diberikan ketika anak menangis (merasa lapar). Dari wawancara tentang kendala dalam pemberian ASI eksklusif didapatkan bahwa tidak ada 
Faktor Penyebab Kejadian Stunting... (Ricky Dwi Satria, Samino Martono, dan Christin AF)

kendala dalam melakukan ASI eksklusif. Hal ini sesuai menurut informan kunci bahwa tidak kendala dari pemberian ASI namun kebersihan saat memberikan ASI perlu diperhatikan. Berikut kutipan dari pernyataan informan kunci.

Melalui wawancara mendalam didapatkan bahwa seluruh informan sudah memahami tentang MPASI. Selanjutnya untuk waktu pemberian MPASI didapatkan bahwa semua Informan memberikan MPASI sebanyak 2-3x sehari sesuai dengan waktu yang telah ditentukan informan. Ketika wawancara tentang jenis variasi makanan yang diberikan dalam pemberian MPASI didapatkan bahwa sebagian informan variasi hanya satu jenis bahan makanan saja setiap harinya. Menurut informan kunci, pemberian MPASI lokal bisa didapat dari bahan yang ada disekitar kita, dengan porsi sesuai dengan isi piringku.

\section{Penyuluhan Stunting dan MPASI Lokal}

Dari wawancara mendalam tentang penyuluhan stunting yang sudah diberikan sebagian besar informan menyatakan bahwa penyuluhan tentang stunting sudah diberikan. Hal ini didukung oleh informan kunci yang menyatakan bahwa penyuluhan tentang stunting sudah sering diberikan. Sama halnya dengan pendapat informan triangulasi yaitu kader, puskesmas sudah memberikan arahan kepada kader untuk penyuluhan tentang stunting. Wawancara yang mendalam tentang penyuluhan MPASI lokal ang sudah diberikan didapatkan bahwa sebagian besar informan menyatakan penyuluhan tentang MPASI hanya tentang emodemo yaitu terkait cara pengolahan MPASI. Sesuai dengan pernyataan dari informan kunci yang menyatakan penyuluhan tentang MPASI memang masih jarang dilakukan. Sama halnya dengan pernyataan triangulasi (kader) menyatakan bahwa penyuluhan MPASI yang sudah dilakukan hanya dari dinas tentang mengolah makanan.

\section{Kendala Dalam Penyuluhan}

Wawancara mendalam tentang kendala dalam penyuluhan didapatkan bahwa masyarakat tidak konsentrasi penuh dalam penyuluhan dan kembali ke pribadi masyarakat masing-masing, apakah menganggap pengetahuan tentang stunting itu penting atau tidak. Hal ini sama seperti yang disampaikan oleh kader sebagai triangulasi, kendala dalam melakukan penyuluhan adalah ketidak hadiran masyarakat.

\section{PEMBAHASAN}

Balita stunting termasuk masalah gizi kronik yang disebabkan oleh banyak faktor seperti kondisi sosial ekonomi, gizi ibu saat hamil, kesakitan pada bayi, dan kurangnya asupan gizi pada bayi. Balita Stunting di masa yang akan datang akan mengalami kesulitan dalam mencapai perkembangan fisik dan kognitif yang optimal (Kemenkes, 2018b). Berdasarkan wawancara tentang stunting didapatkan bahwa sebagian besar informan belum memahami pengertian dari stunting, pendapat dari informan menyatakan bahwa stunting adalah kurang gizi seperti pada kutipan pernyataan. Kemudian sebagian besar informan menyatakan penyebab terjadinya stunting adalah kurang gizi. Selanjutnya, informan pertama mengakui bahwa pada saat hamil sering diajak bekerja (ke kebun). Maka dari itu asupan gizi 
Faktor Penyebab Kejadian Stunting... (Ricky Dwi Satria, Samino Martono, dan Christin AF)

yang dimakan saat hamil berkurang. Hal ini mengarah ke anemia saat hamil dan kekurangan energi kronik pada masa kehamilan, hal ini didukunng pada (ACC/SCN, 2000) nutrisi yang buruk selama masa kehamilan dapat meluas ke janin dan dapat mempengaruhi pertumbuhan dan perkembangan bayi pada masa yang akan datang. Temuan lain yang didapatkan bahwa angka anemia pada ibu hamil berjumlah 2 orang dari 14 ibu hamil dengan persentase $(14,2 \%)$.

Berdasarkan wawancara tentang pencegahan stunting sebagian besar informan hanya menyatakan pencegahan stunting yaitu berikan makanan bergizi. Pencegahan dari stunting menurut sebagian besar informan hanya mengarah pada penatalaksanaan kuratif yaitu memberi makanan yang bergizi pada anak. Selanjutnya, dampak dari stunting yaitu penurunan fungsi kognitif. Berdasarkan hasil wawancara ini peneliti menganalisa bahwa tingkat pengetahuan dari informan terkait stunting berada pada tahapan tahu. Tahapan ini adalah tahapan pengetahuan paling dasar. Informan dengan tingkat pengetahuan "tahu", mereka hanya mampu recall (mengingat kembali) ingatan yang lalu. Kelemahannya adalah hanya sekedar mengingat kembali tanpa adanya upaya memahami maupun menerapkan. Ibu dengan tingkat pengetahuan yang baik tentu dapat menerapkan sikap yang baik, dan akan menerapkan pengetahuannya dalam mengasuh anaknya.

Salah satu informan mengatakan bahwa ia mengetahui anaknya stunting ketika pemeriksaan rutin di posyandu. Hal ini tentu menguatkan asumsi bahwa sebelum anak informan tersebut belum terdeteksi stunting, informan tidak mengetahui ciri-ciri dari kurangnya tinggi badan dibandingkan usia anak atau gagal tumbuh. Peneliti berpendapat bahwa kurangnya pengetahuan informan, terlebih lagi berada pada tingkat "tahu" berdampak pada kejadian stunting. Hal ini disebabkan oleh ketidaktahuan ibu tentang apa itu stunting yang berkelanjutan pada kurangnya pemahaman terhadap upaya pencegahan stunting, serta ketidaktahuan terhadap pola asuh yang baik dan benar. Bahkan ibu yang tahu sekalipun tentang apa itu stunting, belum mampu memahami tentang stunting sehingga sulit mengaplikasikan sikap yang tepat dalam upaya pencegahannya.

Namun menurut observasi peneliti, kurangnya pengetahuan informan terkait stunting dikarenakan kurangnya partisipasi informan dalam penyuluhan, dikarenakan jarak tempuh yang cukup jauh yaitu \pm 8 $\mathrm{km}$ antara rumah penduduk ke puskesmas. Serta akses jalan yang masih buruk dapat menghambat keinginan informan dalam menghadiri kegiatan penyuluhan. Selain itu faktor media seperti smartphone yang belum dimiliki informan sehingga informan tidak dapat mencari pengetahuan tentang stunting melalui internet. Faktor lain yang dapat mempengaruhi stunting yaitu tingkat pendidikan orang tua, sosio ekonomi, sosio budaya dan lingkungan. Hal ini dapat dilihat dari kondisi keluarga dengan anak stuning, dimana pendapatan yang didapat masih terbilang kurang.

Pentingnya memberikan pengetahuan pada ibu dan calon ibu tentu dapat mengurangi risiko kejadian stunting. Puskesmas dapat memberikan edukasi kepada kader setempat 
Faktor Penyebab Kejadian Stunting... (Ricky Dwi Satria, Samino Martono, dan Christin AF)

sehingga kader dapat bergerak memberikan arahan kepada warga sekitar. Penyuluhan seharusnya tidak dilakukan di dalam forum saja, melainkan bisa melalui konsling rutin saat pemeriksaan di posyandu yang dilakukan, atau bisa dengan membagikan pamflet. Selain itu kader dapat membuat grup diskusi di tiap desa mengingat jarak anatara rumah dan posyandu cukup jauh hal ini dapat membantu meningkatkan partisipasi tiap ibu dalam meningkatkan pengetahuan. Metode diskusi dan penyuluhan yang dapat digunakan salah satunya berupa brainstroming. Tujuanya yaitu dapat mengubah pola pengetahuan ibu atau calon ibu yang tadinya tahu menjadi memahami dan berlanjut menjadi dapat mengaplikasikan semua pengetahuan yang dimiliki dalam upaya pencegahan stunting. Melakukan grup diskusi seperti brainstroming yang rutin tentu lebih efesien dibandingkan hanya penyuluhan yang dilakukan oleh fasilitator. Karena jika dengan penyuluhan saja, hanya sebagian masyarakat yang dapat berkonsentrasi terhadap isi penyuluhan, sedangkan dengan metode brainstroming masyarakat dapat menerima umpan balik dari pengetahuan yang disampaikan dan menggali ilmu lebih dalam lagi dengan cara mereka sendiri.

\section{ASI}

Berdasarkan wawancara tentang ASI semua informan melakukan IMD. Pernyataan ini sesuai dengan informan kunci yang menyatakan bahwa bidan-bidan sudah melakukan IMD kepada ibu yang baru melahirkan. Namun informan kunci masih menyatakan bahwa terdapat kendala pelaksanaan IMD. Kendala tersebut seperti pemaknaan IMD bagi tenaga penolong persalinan. Pelaporan hasil pelaksanaan IMD yang ternyata hanya meletakkan bayi di dada ibu tanpa menilai apakah bayi menyusu atau tidak. Selain itu, ketidaksabaran tenaga penolong persalinan menunggu bayi higga berhasil menyusu. Semua informan juga memahami apa itu ASI dapat. Semua informan sudah menerapkan ASI eksklusif dan untuk semua informan memberikan ASI eksklusif dengan frekuensi sesuai kemauan bayi, jika bayi menangis (lapar) informan langsung memberikan ASI. Dari semua informan tidak ada yang memiliki kendala dalam memberikan ASI. Namun satu informan memberikan ASI eksklusif hingga usia 8 bulan, karena anak tidak mau makan makanan lain selain ASI dengan pernyataan informan. Dilihat dari jumlah bayi yang diberikan ASI eksklusif berjumlah 9 bayi dari 13 bayi dengan persentase (69.2\%).

ASI eksklusif adalah pemberian ASI selama 6 bulan kehidupan bayi, sesuai dengan namanya ASI diberikan pada bayi tanpa adanya pendamping makanan lain selama 6 bulan dan bayi benar-benar hanya mendapat asupan gizi dari ASI selama kurun waktu 6 bulan itu (Paramashanti, 2019). Menurut (Lestari, Hasanah and Nugroho, 2018) terdapat hubungan yang signifikan antara pemberian ASI eksklusif dengan kejadian stunting. Lebih banyak anak dengan status gizi normal ketika diberikan ASI eksklusif dibandingkan dengan yang tidak ASI eksklusif. ASI merupakan faktor pelindung terhadap stunting, dimana anak yang tidak diberikan ASI eksklusif berisiko terkena stunting dibandingkan anak yang diberikan ASI eksklusif. Namun, faktor lain 
Faktor Penyebab Kejadian Stunting... (Ricky Dwi Satria, Samino Martono, dan Christin AF)

yang menyebabkan stunting adalah berat badan lahir rendah. Temuan dari penelitian ini anak dengan berat badan lahir rendah memiliki risiko terkena stunting lebih tinggi dibandingkan dengan anak dengan berat badan lahir normal.

Berdasarkan penelitian, diperoleh data anak stunting diberikan ASI eksklusif hingga usia 6 bulan namun masih memiliki tinggi badan yang tidak sesuai dengan usia. Cara pemberian ASI sangat penting, pemberian ASI yang lebih dari 6 bulan tentu menyebabkan asupan gizi anak tidak tercukupi. Setelah usia 6 bulan, pemberian ASI harus didampingi oleh MPASI karena ASI saja sudah tidak mampu mencukupi kebutuhan energi dan zat gizi.

Menurut observasi peneliti kebersihan dalam praktik pemberian ASI juga harus dipertimbangkan. Pemberian ASI tanpa mencuci tangan dan membersihkan area payudara tentu bisa menyebabkan kesakitan pada bayi diakibatkan oleh kuman atau bakteri yang menyebabkan infeksi. Terlebih saat observasi ditemukan ibu yang langsung menyusui anak sehabis bekerja dari ladang tanpa mencuci tangan. Infeksi dapat menyebabkan kejadian stunting sehingga pemberian ASI eksklusif masih menjadi faktor proteksi terhadap kejadian stunting melalui mekanisme peningkatan imunitas anak. Serta didapatkan bahwa 2 anak dari informan lahir dengan berat badan lahir rendah. Peneliti berpendapat, bayi dengan berat badan lahir rendah memiliki risiko terkena stunting. Dikarenakan anak dengan riwayat berat badan lahir rendah memiliki riwayat retradasi pertumbuhan didalam rahim, baik dalam bentuk akut atau kronis.
Terhambatnya pertumbuhan anak di dalam rahim bisa terjadi karena faktor dari ibu sebelum atau saat masa kehamilan yang kekurangan gizi, anemia pada masa kehamilan, dan penyebab yang lainnya. Meskipun anak diberikan ASI eksklusif sekalipun tidak menutup kemungkinan bahwa anak tidak akan terkena stunting, karena penyebab dari stunting tidak hanya berkaitan dengan pemberian ASI eksklusif.

\section{MPASI}

Sebagian besar informan sudah mengetahui tentang pengertian MPASI. Namun variasi MPASI yang diberikan hanya satu jenis makanan tambahan dikarenakan anak sering bosan. Namun menurut informan kunci untuk penyuluhan MPASI memang baru pertama kali dilakukan, yaitu demo. MPASI merupakan makanan serta minuman bervariasi yang khusus diberikan kepada bayi. MPASI dibagi menjadi dua, yaitu MPASI yang dibuat dirumah sendiri (MPASI keluarga) dan MPASI siap saji (pabrikan). Seorang ibu harus mengetahui kuantitas dan jumlah serta variasi MPASI yang diberikan harus mencukupi kebutuhan bayi, namun tentu saja dengan kualitas gizi yang seimbang (Paramashanti, 2019). MPASI dimulai dari usia 6 bulan hingga 23 bulan yang diberikan dalam bentuk tekstur tertentu sesuai dengan usia balita. Pada usia 6-9 bulan berupa makanan bertekstur bubur kental diberikan 2-3 kali sehari, usia 9-12 berupa makanan cincang halus, cincang kasar atau yang dapat dipegang anak diberikan 3-4 kali sehari, dan usia diatas 12 tahun berupa makanan keluarga yang diberikan 3-4 kali sehari (IDAI, 2018). Pemberian MPASI 
Faktor Penyebab Kejadian Stunting... (Ricky Dwi Satria, Samino Martono, dan Christin AF)

memerlukan strategi seperti, berikan berbagai pilihan rasa dan jenis makanan sehat untuk anak terutama protein hewani seperti telur, ikan, daging yang diberikan dalam keadaan yang benar-benar matang. Jangan memberikan jus dikarenakan jus mengandung gula dan itu akan membuat anak menjadi cepat kenyang. Jangan paksa anak untuk makan hal ini akan membuat anak menolak dan susah menghabiskan makanan. Serta saat memberikan makanan jalinlah komunikasi agar membantu perkembangan anak dan dapat membangun hubungan keluarga yang kuat (IDAI, 2018). Hal ini sejalan dengan penelitian oleh (Nurkomala, 2018) anak yang menerima variasi MPASI yang sedikit akan menyebabkan stunting.

Menurut penelitian (Brilliantika, 2016) melakukan praktik responsive feeding penting kerena dapat membantu anak-anak stunting untuk meningkatkan asupan gizi melalui peningkatan penerimaan makan, meningkatkan kemampuan motorik melalui latihan sendiri dan mencapai status gizi yang lebih baik. Pengetahuan yang kurang terhadap cara pemberian makan pada anak dapat meningkatkan risiko kejadian stunting (Briliantika, 2016). Tumbuh kembang balita usia 6-24 bulan merupakan masa yang sangat menghawatirkan, (King, 1996) dalam buku Sunarsih menyebutkan masa ini adalah masa keritis karena pertumbuhan anak masih cepat, bahkan disertai dengan pertumbuhan otak yang cepat, akan tetapi pada masa ini sering diberikan makanan yang gizinya terbilang kurang dan mudah membuat anak kenyang akan berdampak buruk pada anak (Tri et al., 2019). Walaupun persentasi pemberian MPASI pada Kampung
Tawang Negri mencapai 73,9\%, namun jika cara pemberian MPASI yang tidak adekuat dapat mempengaruhi pertumbuhan anak. Rendahnya pengetahuan informan tentang gizi seimbang dan pola asuh dalam memberikan makanan tambahan menjadi salah satu faktor dalam memberikan MPASI. Disamping itu, pendapatan keluarga yang masih terbilang kurang dapat mempengaruhi kejadian stunting pada anak. Keluarga tidak dapat membeli berbagai jenis makanan karena keterbatasan dana.

Pemberian makanan tambahan seperti biskuit untuk balita kekurangan gizi sudah dilakukan, akan tetapi ibu tidak memberikan biskuitnya secara teratur dengan alasan anak tidak mau makan biskuit tersebut. Bahkan makanan tambahan seperti biskuit juga diberikan kepada anak atau keluarga yang tidak memiliki masalah gizi. Salah satu informan menyatakan bahwa untuk mendapatkan PMT berupa biskuit harus membayar Rp.2000.- berikut kutipan pernyataan informan.

Selain itu, pihak puskesmas dan posyandu belum memberikan penyuluhan yang rutin tentang pemberian MPASI yang mengakibatkan ketidaktahuan ibu dalam memberikan MPASI yang tepat dan benar, ibu hanya memberikan makan pada bayi hanya sebatas agar bayi merasa kenyang tetapi tidak untuk sehat. Penyuluhan MPASI yang pertama kalipun tentang emodemo dari Dinas Kesehatan yaitu berupa program stunting tentang demo masak untuk makanan lokal bagi anak, namun sebagian warga juga tidak mengikuti kegiatan tersebut. Serta Masyarakat hanya mengikuti penyuluhan-penyuluhan saja, namun tidak memahami isi dan maksud dari

Jurnal Dunia Kesmas, Vol. 9 No. 3, Juli 2020, hal. 395-403

412

ISSN 2301-6604 (Print), ISSN 2549-3485 (Online)

http://ejurnalmalahayati.ac.id/index.php/duniakesmas/index 
Faktor Penyebab Kejadian Stunting... (Ricky Dwi Satria, Samino Martono, dan Christin AF)

$\begin{array}{lll}\text { penyuluhan } & \text { tersebut, } & \text { yang } \\ \text { menyebabkan } & \text { masyarakat tidak }\end{array}$ mengerjakan apa yang disampaikan oleh fasilitator pada saat penyuluhan. Oleh sebab itu, perlu dilakukannya pendekatan kekeluargaan terhadap masyarakat menilai masyarakat belum sepenuhnya mengerti dampak dari stunting sehingga mereka bersikap biasa saja selagi anak tidak memiliki penyakit yang cukup parah. Pendekatan keluarga dilakukan oleh puskesmas atau posyandu guna memberi pengetahuan kepada keluarga secara langsung. Selain itu, dengan melakukan pendekatan keluarga puskesmas akan dapat mengenali masalah-masalah kesehatan yang dihadapi keluarga secara lebih menyeluruh.

Melalui pendekatan keluarga, puskesmas dibantu oleh kader atau tokoh masyarakat dapat memberikan pengetahuan agar mengubah perilaku masyarakat dalam memberikan makanan pada anak. Pendekatan keluarga dapat dilakukan dengan cara memberikan edukasi terkait cara mengolah makanan lokal dengan biaya yang murah dan kecukupan gizi terpenuhi yang ada di lingkungan masyarakat. Seperti membuat olahan nugget dengan tumbukkan tempe yang di balut oleh daun bayam lalu di goreng, dan lain sebagainya. Selain itu, memberikan pengetahuan tentang responsive feeding sangat penting dilakukan. Pengetahuan yang kurang mengenai responsive feeding meliputi keanekaragaman makanan, cara memberikan makan secara aktif, lingkungan yang dibutuhkan, respon ketika adanya penolakan makan dari anak, memberikan makan pada saat anak sakit dan dalam masa pemulihan, dan menghidangkan makanan kepada anak memiliki dampak terhadap nafsu makan anak dan status gizinya.

Memberikan edukasi berupa pemberian MPASI yang benar pola prilaku masyarakat menjadi lebih mandiri. Puskesmas atau Posyandu dapat memberikan demo terkait pemberian makanan gizi seimbang dengan menggunakan makanan lokal yang tidak perlu mahal namun memenuhi kebutuhan gizi setiap harinya. Membuat makanan lokal menjadi makanan yang tidak membosankan bagi anak sesuai dengan usia balita dan sesuai dengan "isi piringku" yaitu terdiri dari $1 / 3$ makanan pokok, $1 / 3$ sayuran, $2 / 3$ lauk, dan 2/3 buah-buahan. Puskesmas atau posyandu perlu memberikan pamflet-pamflet tentang stunting dan cara pencegahannya. Kemudian perlu membuat forumforum diskusi agar dapat meningkatkan pengetahuan masyarakat. Jika masyarakat tidak datang pada saat pemeriksaan rutin diharapkan kader dapat mendatangi rumah warga. Dengan cara ini bisa mengatasi ketidaktahuan masyarakat dan dapat memberi memotivasi masyarakat secara langsung untuk memperbaiki pola pikir, kondisi kesehatan lingkungan dan berbagai faktor risiko lain yang selama ini merugikan kesehatan.

\section{KESIMPULAN}

Sebagian besar informan belum memahami stunting, baik dari segi pengertian, penyebab, dampak dan pencegahan. Dikarenakan tingkat pengetahuan informan yang hanya sebatas "tahu" berdampak pada ketidak tahuan dalam memahami maupun mengaplikasikan ilmu pengetahuan yang dimiliki dalam melakukan upaya pencegahan stunting, sehingga dapat

Jurnal Dunia Kesmas, Vol. 9 No. 3, Juli 2020, hal. 395-403

ISSN 2301-6604 (Print), ISSN 2549-3485 (Online)

http://ejurnalmalahayati.ac.id/index.php/duniakesmas/index 
Faktor Penyebab Kejadian Stunting... (Ricky Dwi Satria, Samino Martono, dan Christin AF)

meningkatkan angka kejadian stunting. Disamping itu pemberian MPASI yang tidak bervariasi dapat berdampak pada pertumbuhan anak, dimana masa pemberian MPASI merupakan golden periode untuk tumbuh kembang anak. Maka dari itu perlu dilakukan grup diskusi yang rutin saat melakukan pendekatan keluarga, untuk memberikan pengetahuan kepada masyarakat secara menyeluruh.

\section{DAFTAR PUSTAKA}

ACC/SCN (2000) Low birthweight Report of a Meeting in Dhaka, Nutrition Policy Paper 18. Bangladesh: Nutrition Policy Paper 18.

Briliantika, F. (2016) 'Faktor Determinan Perilaku Responsive Feeding pada Balita Stunting Usia 6 - 36 Bulan', Jurnal of Nutrition College, 5 Jilid I, pp. 120-129.

E-PPGBM (2019) Lokasi Kampung Stunting. Lampung Tengah: Dinas Kesehatan Kabupaten Lampung Tengah.

Evi Martha (2016) Metodologi Penelitian Kualitatif Untuk Bidang Kesehatan. Jakarta: PT Rajagrafindo Persada.

IDAI (2018) Pemberian Makanan Pendamping Air Susu Ibu (MPASI). UKK Nutrisi dan Penyakit Metabolik Ikatan Dokter Anak Indonesia.

Kemenkes (2018a) Buku Saku Pemantauan Status Gizi Tahun
2017. Kementrian Kesehatan.

Kemenkes (2018b) 'Buletin Stunting', Kementerian Kesehatan Republik Indonesia, 301(5), pp. 11631178.

Lestari, E. D., Hasanah, F. and Nugroho, N. A. (2018) 'Correlation between non-exclusive breastfeeding and low birth weight to stunting in children', Paediatrica Indonesiana, 58(3), pp. 123-7. doi: 10.14238/pi58.3.2018.123-7.

Nurkomala, S. (2018) Praktik Pemberian Mpasi (Makanan Pendamping Air Susu Ibu) Pada Anak Stunting Dan Tidak Stunting Usia 6-24 Bulan. Journal Of Nutrition College. Available at: http://ejournal3.undip.ac.id/index. php/jnc/\%OAPRAKTIK.

Paramashanti, B. A. (2019) Gizi Bagi Ibu \& Anak. Yogykarta: PT. Pustaka Bru.

Ramadhan, R., Ramadhan, N. and Fitria, E. (2018) 'Determinasi Penyebab Stunting di Provinsi Aceh', Sel Jurnal Penelitian Kesehatan, 5(2), pp. 68-76. doi: 10.22435/sel.v5i2.1595.

Sugiyono (2018) Metode Penelitian Kualitatif Untuk Penelitian Yang Bersifat: Eksploratif, Enterpretif, Interaktif dan Konstruktif. 3rd edn. Bandung: Alvabeta.

Tri, S. et al. (2019) Buku Pintar Pemberian Makan Bayi dan ANak. Edited by Nita. Bandung: PT Remaja Rosdakarya Offset. 